Enzymatic digestion とラット視床下部 PRF 活性

\author{
東北大学医学部座科婦人科学教室 (主任: 鈴木雅洲教授) \\ 高橋 克幸, 若井貞子, 和田 裕一, 斎滕晃 \\ 星合昊, 古橋 信晃, 鈴木 雅洲
}

\title{
Activation of Prolactin Releasing Activity of Pregnant Rat Hypothalamic Extract by Enzymatic Digestion
}

\author{
Katsuyuki TAKAHASHI, Teiko WAKAI, Yuichi WADA, \\ Akira SAITO, Hiroshi HOSHIAI, Nobuaki FURUHASHI \\ and Masakuni SUZUKI \\ Department of Obstetrics and Gynecology, Tohoku University School of Medicine, \\ Sendai, Japan.(Director : Prof. M. Suzuki, M.D.)
}

The prolactin releasing activity of the pregnant rat hypothalamic extract(HE). was previously reported. In the present study, HE was boiled or enzymatically digested so as to investigate the properties of the prolactin releasing factor in $\mathrm{HE}$.

HE was subsequently injected into puerperal lactating rats, and serum and pituitary prolactin levels were determined by double antibody radioimmunoassay. Boiling was done at $100^{\circ} \mathrm{C}$ for $15 \mathrm{~min}$, and enzymatic digestion was carried out with either trypsin or alpha-chymotrypsin at $37^{\circ} \mathrm{C}$ for $6 \mathrm{hrs}$ in Tris- $\mathrm{HCl}$ buffer $\mathrm{pH} 7.8$, and terminated by freezing with acetone-dry ice.

Boiled HE caused an increase in serum prolactin levels as much as non-treated HE 2 and $4 \mathrm{hrs}$ after administration. After injection of tryptic digested HE, serum prolactin levels increased 3 times as much as control $4 \mathrm{hrs}$ later, but pituitary prolactin levels decreased significantly 2 hrs Iater. After injection of chymotryptic digested HE, serum prolactin levels increased 6.5 times as much as control 4 hrs later, but pituitary prolactin levels decreased 2 and $4 \mathrm{hrs}$ later.

Chymotryptic digestion was followed by ultracentrifugation at $105,000 \times \mathrm{g}$ for $30 \mathrm{~min}$, and the supernatant and precipitate were injected into the lactating rats. The supernatant of digested $\mathrm{HE}$ caused the highest increase of serum prolactin levels. On the other hand, the supernatant of digested HE made in pituitary prolactin levels decreased much more than the supernatant of non-digested HE. The prolactin releasing activity existed in the supernatant of the digested HE.

The present report suggests that the prolactin releasing factor in $\mathrm{HE}$ is heat 第52巻 第 6 号 
stable, and seems to be a polypeptide and appears to be activated by solublization as a result of enzymatic digestion.

\section{I 緒古}

一般に下垂体からの prolactin (PRL) 分泌は視床下部より放出される PIF (PRL Inhibiting Factor) と PRF (PRL Releasing Factor) の2者によって調節されるといわれている. そして, PIF と PRF の抽 出が試みられる一方で出 フ , PIF と PRF の分泌調節が論じられている. 他方, 脳内アミンである dopamine $^{8,9)}, \mathrm{L}-\mathrm{dopa}^{10)}$, serotonin 及び melatonin ${ }^{11)}{ }^{13)}$ が所謂 dopaminergic neuron や serotonergic neuron を介して PIF と PRF の分泌を調節するという説や 11) 13), pineal gland が視床下部のより上位で PIF や PRF の放出に関与する, という報告す出されている141. しかし, PIF あ PRF あどちらあその本 体は明らかではなく，比較的低分子の polypeptide であろうと推察されているにすぎない.

本実験は我々が既に報告した妊娠末期におけるラット視床下部抽出物の PRL 放出活性 (PRF 活性) ${ }^{1) ~ 3) ~}$ を次の 2 点で検討し, 本体解明の 1 つの approach とした. 即ち, 視床下部抽出物の(1)加熱処理と(2) enzymatic digestion 後の PRF 活性の変動を検討した.

後者の enzymatic digestionは主にアミノ酸配列の決定に利用されるが(5) 22), 最近では牛の fibrinogen の kinetic model の推定に用いた報告も出されている23. 又, ヒトの growth hormone(hGH)の plasmin による digestion が hGH の PRL 生物活性を増加させた報告や24), 硫安分画後に salt-free powder とし た alkaline phosphatase を tryptic digestion により activate した報告も出されており25), enzymatic digestion が生物活性を増加させる作用をむつととも否定できない. 従って, 本抽出物の enzymatic digestion には活性因子の活性部位の推定か, 或いは活性因子の精製の手段のどちらかの可能性が在るものと考 えて本実験をおこなった。

\section{II 実 験 方 法}

\section{1. 動 物}

実験動物として Wister 系ラットを使用した。ラットは水と慨を自由に与えて飼育した。妊娠末期のラッ

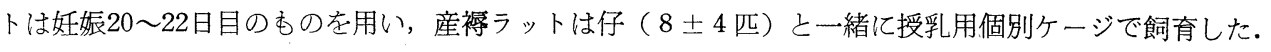

\section{Hypothalamic extract (HE)}

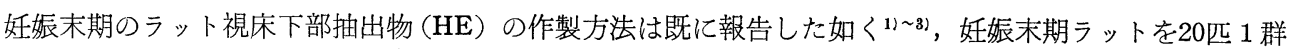
とし, 視床下部摘出後, 直ちに acetone-dry ice で凍結, $1.5 \mathrm{mM} \mathrm{MgCl} / 30 \mathrm{mM}$ Tris-HC buffer, $\mathrm{pH}$ $7.8,18.0 \mathrm{ml}$ で homogenizel し， $20 \mathrm{kHz}, 10$ 分間 sonic oscillator にかけて cell free の状態としたも のを, $25,000 \times \mathrm{g}, 30$ 分, $2{ }^{\circ} \mathrm{C}$ 亿於て超遠心して上清を得た. 抽出操作は全て $4{ }^{\circ} \mathrm{C}$ の cold room.で行ない, 抽出液は $-80^{\circ} \mathrm{C}$ で保存した。

\section{HE の処理方法}

a. HE の加熱処理

$\mathrm{HE}$ を $100^{\circ} \mathrm{C}, 15$ 分, 水浴上で加熱し， $2,000 \mathrm{rpm}, 15$ 分遠心して上清を実験に供した.

b. Enzymatic digestion

Proteolysis は pH 7.8 の $1.5 \mathrm{mM} \mathrm{MgCl} / 30 \mathrm{mM}$ Tris- $\mathrm{HCl}$ buffer 中, $37^{\circ} \mathrm{C}$ で trypsin と $\alpha$-chymotrypsin により行なった. 予備実験として反応後の反応液の酵素活性を tyrosin ethylester 加水分解後の 吸収波長の変化により測定したが361，残存酵素活性及び contamination は否定できた. trypsin は Sigma Type III, 11,400 BAEE units/mg protein, $\alpha$-chymotrypsin は Sigma Type II, 60 BTEE units/mg solid のあのを用い, 6 時間 incubation 後, acetone-dry ice により反応を停止した. 酵素と基質即ち HE 
の濃度比は $1: 50$ (蛋白濃度) とした.つまり incubation mixture は酵素 $3.2 \sim 3.6 \mathrm{mg} \mathrm{protein} / \mathrm{ml} 0.1$ $\mathrm{ml}$ に, 基質 $8.0 \sim 9.0 \mathrm{mg}$ protein $/ \mathrm{ml} 2.0 \mathrm{ml}$ であった.

c. Enzymatic digestion 後の ultracentrifuge

$\alpha$-chymotryptic digestion をした HE の一部を，105,000× g，30分超遠心し，上清と沈渣を分離した。 上清はそのまま, 沈渣は前述の Tris-HCl buffer に䋰濁し, 活性の検討をした.

\section{HE の PRF 活性}

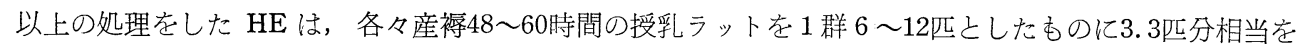
皮下注投与した。投与後 $2 ， 4$ 時間後の血清と下垂体 PRL を NIAMD より提供された Rat PRL を用い て double antibody radioimmunoassay にて測定した. standard は NIAMD-Rat-PRL-Rp 1, ヨード化 用抗原は NIAMD-Rat-PRL-I-1，抗体は NIAMD-Anti-Rat-PRL-S-2 であった.

\section{III 実 験 成 績}

\section{HE の PRF 活性に及ぼす加熱処理の影響}

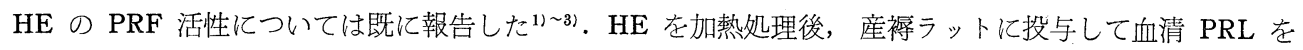
測定し Fig.1 の結果を得た. control 群としては無処理の HE を投与した産袝ラットを用いた. 血清 PRL は加熱処理投与群で投与 2 時間後に $69.2 \pm 12.6 \mathrm{ng} / \mathrm{ml}$, 無処理群で $115.4 \pm 32.7 \mathrm{ng} / \mathrm{ml}$ であり, 4 時間後 には加熱処理群 : $187.6 \pm 13.1 \mathrm{ng} / \mathrm{ml}$, 無処理群 : $179.5 \pm 36.4 \mathrm{ng} / \mathrm{ml}$ であった. とれら無処理群と処理群 の值の間には有意差は認められなかった。

\section{HE の tryptic digestion}

trypsin で proteolysis をした HE を座裖 48〜60 時間の授乳ラットに投与し，血清及び下垂体 PRL を 測定した（Fig. 2，3). digested $\mathrm{HE}$ 投与群の血清值は投与 2 時間後に $72.5 \pm 26.4 \mathrm{ng} / \mathrm{ml}$ であったが，4 時間後には $263.3 \pm 48.9 \mathrm{ng} / \mathrm{ml}$ と増加した. 一方, control 群は 2 時間後に $125.1 \pm 37.0 \mathrm{ng} / \mathrm{ml}, 4$ 時間後 に $110.7 \pm 21.9 \mathrm{ng} / \mathrm{ml}$ と変動を示さなかった. digested HE 投与群と control 群とを比較すると，2時間 では有意差は認められなかったが， 4 時間で有意の $\mathrm{PRL}$ 值の上昇が認められた $(\mathrm{P}<0.01)$ (Fig. 2).

下垂体 PRL は， digested HE 投与 2 時間後に $1093.0 \pm 125.8 \mathrm{ng} / \mathrm{mg}$ AP (Anterior Pituitary) とな り, control の $1547.5 \pm 222.7 \mathrm{ng} / \mathrm{mg} \mathrm{AP}$ と比べ有意に低值を示した $(\mathrm{P}<0.01)$. しかし, 4 時間後には 酵素処理群で $1839.5 \pm 275.8 \mathrm{ng} / \mathrm{mg}$ AP, control 群で $1949.1 \pm 101.5 \mathrm{ng} / \mathrm{mg}$ AP となり, 有意の差は認

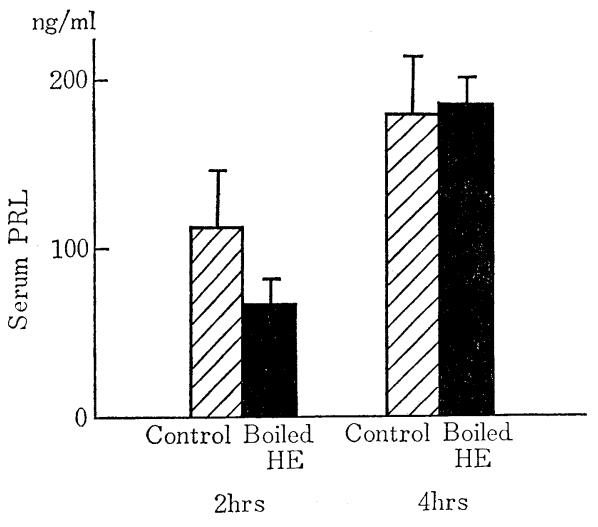

Fig. 1. Serum prolactin levels after administration of boiled $\mathrm{HE}$ and non-treated $\mathrm{HE}$ in lactating rats.

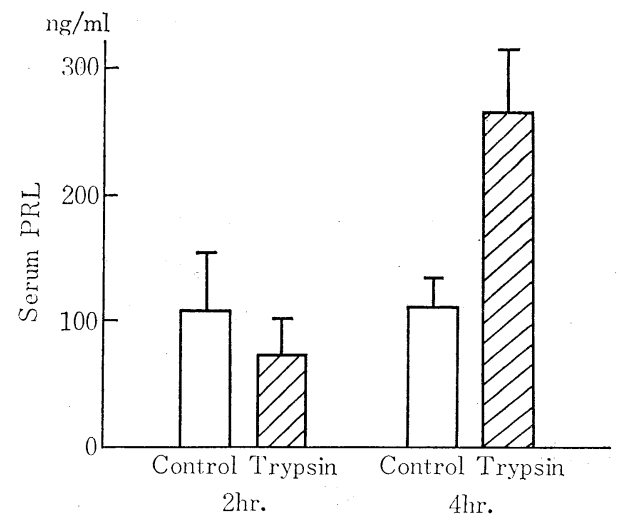

Fig. 2. Serum prolactin levels after administration of tryptic digested $\mathrm{HE}$ in lactating rats. 


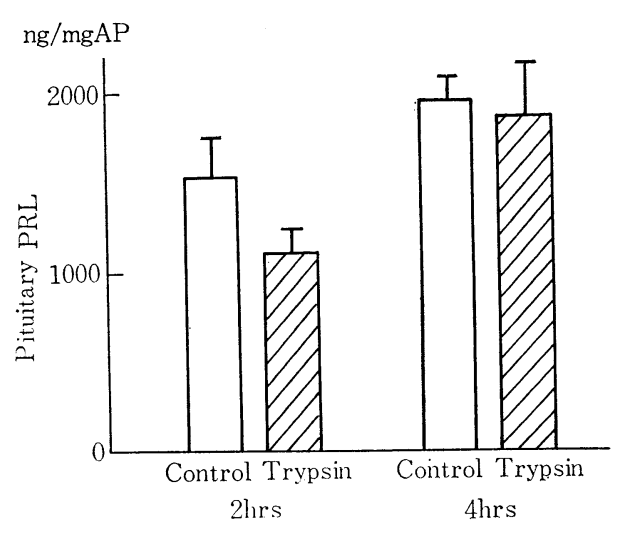

Fig. 3. Pituitary prolactin levels after administration of tryptic digested $\mathrm{HE}$ in lactating rats.

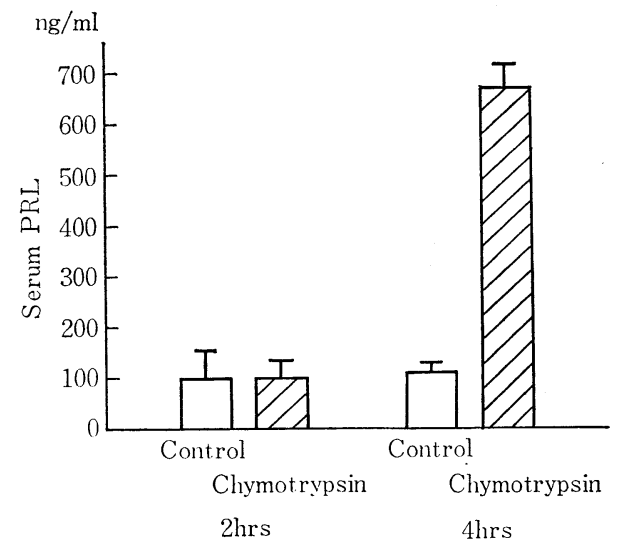

Fig. 4. Serum prolactin levels after administration of chymotryptic digested $\mathrm{HE}$ in lactating rats.

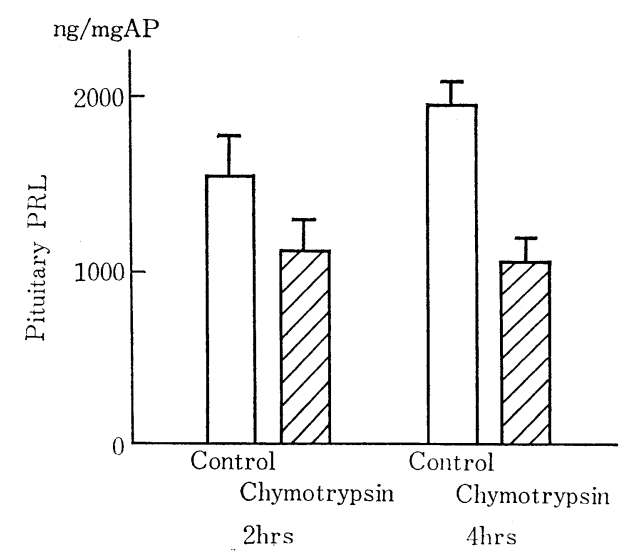

Fig. 5. Pituitary prolactin levels after administration of chymotryptic digested $\mathrm{HE}$ in lactating rats.

められなかった (Fig. 3).

\section{HE の chymotryptic digestion}

chymotryptic digested HE を産袝授乳ラットに投与し，血清と下垂体 PRL の変動を見た $(F i g .4,5)$. digested HE を投与すると，血清值は 2 時間後に $106.0 \pm 30.6 \mathrm{ng} / \mathrm{ml}$ となったが，乙の值は control 群の $125.1 \pm 37.0 \mathrm{ng} / \mathrm{ml}$ に比べ有意差はなかった。しかし，4 時間後には digested HE 投与群で $667.5 \pm 45.0$ $\mathrm{ng} / \mathrm{ml}$, control 群で $110.7 \pm 21.9 \mathrm{ng} / \mathrm{ml}$ となり, digested $\mathrm{HE}$ 投与群の血清 PRL 值は control の6.5倍 に増加した $(\mathrm{P}<0.001)$ (Fig. 4).

一方，下垂体 PRL 值は control 群では投与 2 時間後に $1547.5 \pm 222.7 \mathrm{ng} / \mathrm{mg} \mathrm{AP}, 4$ 時間後に 1949.1 $\pm 101.5 \mathrm{ng} / \mathrm{mg} \mathrm{AP}$ であったのに対し, digested HE 投与群の下垂体 PRL 值は 2 時間後 1112.2 181.2 $\mathrm{ng} / \mathrm{mg} \mathrm{AP}, 4$ 時間後に $1036.8 \pm 153.3 \mathrm{ng} / \mathrm{mg} \mathrm{AP}$ と, いずれも control に比べ有意に低值を示した（P $<0.05, \mathrm{P}<0.01$ ) (Fig. 5). 
(小括)

以上の結果を血清值についてまとめたのが Table 1 である.

Table 1.

Effects of boiling and enzymatic digestion on PRF activity of HE.

(serum PRL levels $4 \mathrm{hrs}$ after)

\begin{tabular}{l|r|l}
\hline Nontreated HE & $100.0 \pm 20.3 \%$ & \\
Boiled HE & $104.5 \pm 7.3 \%$ & $\mathrm{NS}$ \\
Incubated HE without enzyme & $61.7 \pm 12.2 \%$ & $\mathrm{P}<0.01$ \\
Tryptic digested HE & $146.7 \pm 27.2 \%$ & $\mathrm{NS}$ \\
Chymotryptic digested HE & $371.7 \pm 25.1 \%$ & $\mathrm{P}<0.01$ \\
\hline
\end{tabular}

無処理 $\mathrm{HE}$ 投与 4 時間後の血清值を $100.0 \%$ とした時の各々の処理 $\mathrm{HE}$ 投与群の血清值の割合を\%で示 した， $100^{\circ} \mathrm{C} ， 15$ 分の加热処理は $\mathrm{HE}$ の PRF 活性に影響を及ぼしていないが， $37^{\circ} \mathrm{C}, 6$ 時間の incubation は活性の有意の低下を招くことが認められた。しかし, enzymatic digestion によって PRF 活性は上昇 し, tryptic digestion では増加傾向が見られ, chymotryptic digestion では著明な増加が示された。

\section{Chymotryptic digestion 後の supernatant の PRF 活性}

Fig. 6 に $\alpha$-chymotryptic digestion 後, 105,000×g で超遠心して得た上清と, 沈渣を投与した時の血 清 PRL 值を示した. 結果は投与 4 時間後の值である. digested HE の上清投与群では $555.8 \pm 48.9 \mathrm{ng} / \mathrm{ml}$, 酵素を加えないで incubate した control の上清投与群では $153.0 \pm 26.8 \mathrm{ng} / \mathrm{ml}$ と, 上清では digested $\mathrm{HE}$ 投与群に有意の活性の上昇が認められた $(\mathrm{P}<0.01)$. 沈渣投与群では, digested HE 投与で $224.5 \pm$ $36.5 \mathrm{ng} / \mathrm{ml}$, control で $201.2 \pm 51.5 \mathrm{ng} / \mathrm{ml}$ と有意の差はみられなかった. 沈渣と上清とを比較すると, control 群では有意差はなく, digested HE 投与群で上清への活性の移行が見られた $(\mathrm{P}<0.01)$.

下垂体 PRL の変動を Fig. 7 亿示した. digested HE の上清投与群で $1588.4 \pm 335.2 \mathrm{ng} / \mathrm{mgAP}$, control の上清投与群で $2161.5 \pm 205.4 \mathrm{ng} / \mathrm{mg} \mathrm{AP}$ と, control の上清投与群が有意に高值を示した $(\mathrm{P}<0.02)$.

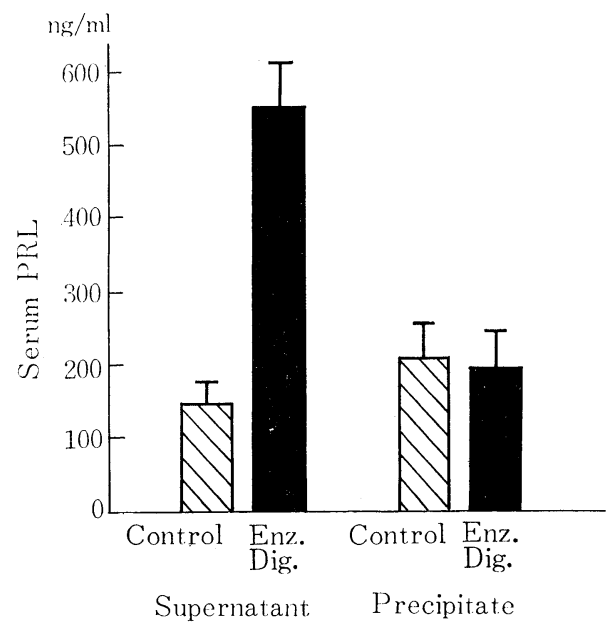

Fig. 6. Serum prolactin levels after administration of supernatant and precipitate of chymotryptic digested HE.

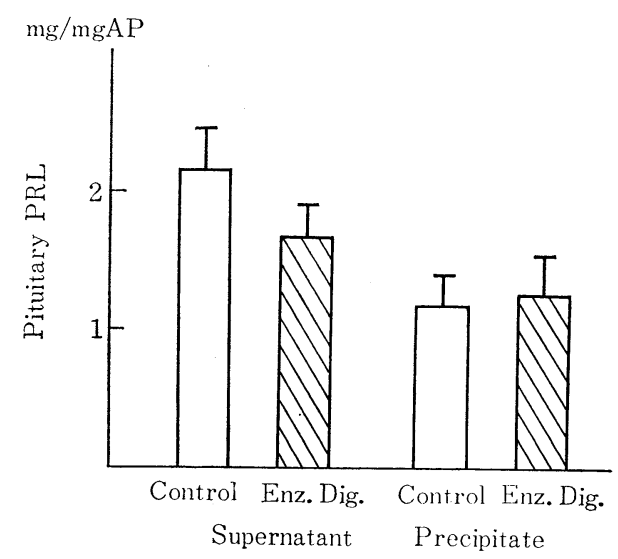

Fig. 7. Pituitary prolactin levels after administration of supernatant and precipitate of chymotryptic digested HE. 
しかし, 沈渣の投与は, digested HE 投与で1304.5土274.1 ng/mg AP, control で $1187.8 \pm 207.7 \mathrm{ng} / \mathrm{mg}$ AP と有意の差はなく, 又, digested HE の沈渣と上清の間にあ有意の活性の差は認められなかった。

\section{IV 考察}

妊娠期におけるラット PRL 分泌増加の機序についての検討は, 中枢性因子ばかりでなく, 卵巣性因子の 関与についても，2，3報告がおこなわれているが，実験条件によって相反する結果が出ている26) 28). そ の原因は, ラット血中 PRL は stress で容易に增加するため 292 ２2，実験条件の設定が難しいととにあると 考えられる. しかし, 最近の研究では産袒授乳ラットが stress に対して抵抗性を有するととが報告されて いる33. その点からして, 本実験の recipient である産䙏授乳ラットは PRF の検討に適しているといえよ う.

視床下部 hormone である TRH は heat stable であることが既に報告されている. 又, PIF は加熱処 理後の hypothalamic extract 中にであその活性が認められる, そこで, 本 HE を加熱処理し, PRF 活性 を検討した. PRF 活性は $100^{\circ} \mathrm{C}, 15$ 分の加热処理を加えても変化しなかったので, $\mathrm{HE}$ 中の活性因子は他の 視床下部性 peptide hormone 同様, heat stable で, おちらく比較的低分子の polypeptideであろうと推 察された.

加熱処理により PRF 活性の変動がおこらなかったので, PRF 活性因子のアミノ酸配列を推測するとと を目的として enzymatic digestion を試みた。しかし, 本 HE が crude extract であったため, 我々の条 件下では活性の低下は打こらず, 却って PRF の上昇がみられた。 enzymatic digestion により活性が上昇 したことから，活性因子が以下の状態にあることが想起された。

（1）活性因子は細胞内蛋白分子などの高分子の polypeptide に包まれている.

（2）活性因子は particulate である.

（3）活性因子の peptide chain が enzymatic digestion で切れると, より活性の高い物質に変わる可能 性がある.

これらのととから考えると, enzymatic digestion は活性因子をより低分子にして可溶画分に移行させた と思わ机る. そして酵素を加えないで 6 時間 incubate すると, HE の PRF 活性は約40\%低下した。従っ て HE 中の PRF 活性因子は heat stable であるが, 長時間室温以上にあって空気に曝されると活性が低 下する性状をすつすのであると推定される. 本実験での抽出操作が cold room で行なわれたことは HE の PRF 活性の保持に重要な役割を果したといえる.

tryptic digestionはHE の PRF 活性を, incubateしない HE と比べてやや上梨させたが, $\alpha$-chymotryptic digestion は PRF 活性を incubate しない HE と比較すると, その 3 倍以上に増加させた。 この 差は両酵素の基質特異性の他に，反応条件が作用して生じたものと考えられる.

chymotryptic digested HE $105,000 \times \mathrm{g}$ で超遠心した際, PRF 活性は digested HE の上清に強く認 められたが, 沈淔及び control 群の上清・沈渣には有意の差がみられなかった。従って, PRF 活性の上清 への移行が認められ, enzymatic digestion による solublization が推察された. 活性が可溶画分に移行し たことは enzymatic digestion 活性因子の精製の有効な手段となり得るととを示㕹している.HE の Sephadex gel filtrationは $105,000 \times \mathrm{g}$ の上清を検体として用い得ることで, 比較的容易になったといえるで あろう。

本実験の結果は妊娠末期のラット視床下部中に peptide 様の PRL 放出活性因子が存在し, 妊娠末期に は PIF に比へ優位に存在するととを示唆した. 近年, PRL の antigonadotropic action が注目されてい るが34),35), PRF の解明はその問題をむ明らかにし得る意味をもつあのと思われる.

結 語

妊娠末期に抽けるWister 系ラット視床下部抽出物(HE)の PRL 放出作用について, 加热処理と enzy- 
matic digestion の面から活性因子に検討を加えた.

1. HE の PRF 活性の検定は，産禔 48〜60 時間の授乳ラットの血清及び下垂体 PRL の変動に基づい て行なった. PRL 值は double antibody radioimmunoassay により測定した.

2. $100^{\circ} \mathrm{C}, 15$ 分の加熱処理後の $\mathrm{HE}$ の PRF 活性は, 投与 2,4 時間後とも無処理 $\mathrm{HE}$ に比較し, 有 意の変化は認められなかった。

3. $\mathrm{HE}$ と $\operatorname{trypsin}$ を $37^{\circ} \mathrm{C}, 6$ 時間, $\mathrm{pH} 7.8$ で incubate した. 投与 2 時間後では血清 PRL 值と control 值の間には有意差は認められなかったが，4時間後に control 群の 3 倍に増加した $(\mathrm{P}<0.01)$. 一方, 下垂 体 PRL 值は 2 時間後に有意に減少し $(\mathrm{P}<0.01), 4$ 時間後に control とほぼ同じ值に戻った.

4. $\mathrm{HE}$ と $\alpha$-chymotrypsin $37^{\circ} \mathrm{C}, 6$ 時間, $\mathrm{pH} 7.8$ で incubate した. 投与 2 時間後では血清 PRL 值と control 值との間には有意の差はなかったが, 4 時間後に control 群の6.5倍に増加した $(\mathrm{P}<0.01)$. 下垂体 PRL 值は $2 ， 4$ 時間後とも control 比べ有意に低值を示した $(\mathrm{P}<0.05, \mathrm{P}<0.01)$.

5. $\alpha$-chymotrypsin と incubate した HE を， $105,000 \times \mathrm{g} ， 30$ 分間超遠心し，上清及び䟘渣とについ て, 各々の PRF 活性を検討した. digested HE の上清投与 4 時間後では, 血清 PRL 值は digested HE の沈渣や, control の上清及び沈渣投与群と比較し, 有意に高值を示した $(\mathrm{P}<0.01)$. digested HE の上清 投与後の下垂体 PRL 值は control の上清投与群に比較し有意に低かった $(\mathrm{P}<0.02)$. とのととより, PRF 活性は digested HE の上清にあるととが判明した.

以上の結果から, 妊娠末期ラット視床下部中の PRL 放出因子の存在が明らかとなった. 活性因子は heat stable で, 比較的低分子の polypeptide であり, enzymatic digestion によって solublization し活性が 高まるものと考えられる.

謝辞

Rat PRL の提供をうけた NIH-NIAMD と本研究の一部に援助をされた米国 Population Council (grant No. M74. 066C) に対し深謝致します。

本論文の要旨の一部は, 第23回日本内分爫学会東部々会総会で発表した.

$$
\text { 文献 }
$$

1）高橋克幸：乳汁分泌関す研究. 第22回日産婦学会北日本連合地方部会総会特別講演要旨, 日産婦会東

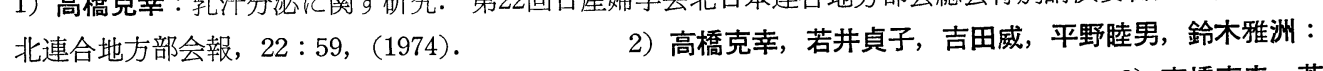
弤娠末期ラッ卜視床下部の Prolactin 分泌促進因子, 日内誌, $51: 284,(1975) . \quad 3 ）$ 高橋克幸, 若 井貞子, 中川公夫, 星合昊, 和田裕一, 鈴木雅洲: 妊娠末期ラット視床下部の Prolactin 分泌促進作用, 日 内誌, 51 : 1015, (1975). $\quad$ 4) Dhariwal, A.P.S., Grosvenor, C.E., Antunes-Rodrigues, J. and McCann, S. M. : Studies on the purification of ovine prolactin-inhibiting factor. Endocrinology, $82: 1236$, (1968). $\quad$ 5) Kamberi, I. A., Mical, R. S. and Porter, J. C. : Pituitary portal vessel infusion of hypothalamic extract and release of LH, FSH and prolactin. Endocrinology, $88: 1294$, (1971). $\quad$ 6) Valverde-R., C., Chieffo, V. and Reichlin, S. R. : Prolactin-releasing factor in porcine and rat hypothalamic tissue. Endocrinology, $91: 982$, (1972). 7) Dular, R., LaBella, F., Vivian, S. and Eddie, L. : Purification of prolactin-releasing and inhibiting factor from beef. $\begin{array}{ll}\text { : Endocrinology, } 94: 563 \text {, (1974). } & \text { 8) Kamberi, I.A., Mical, R.A. and Porter, J. C. : Hypo- }\end{array}$ physial portal vessel infusion : in vivo demonstration of LRF, FRF, and TIF in pituitary stalk plasma. Endocrinology, $89: 1042$, (1971). $\quad 9$ ) Kamberi, I. A., Mical, R. S. and Porter, J. C. : Effect of anterior pituitary perfusion and intra-ventricular injection of catecholamines on prolactin release. Endocrinology, $88: 1012$, (1971). 10$)$ Lu, K.H. and Meites, J.: Effects of L-dopa and serum prolactin and PIF in intact and hypophysectomized, pituitary-grafted rats. Endocrinology, $91: 868$, (1972). 11 ) Kamberi, I.A., Mical, R.S. and Porter, J.C. : Effects 第 52 巻 第 6 号 
of melatonin and serotonin on the release of FSH and prolactin. Endocrinology, $88: 1288$, (1971). 12) Lu, K. H. and Meites, J. : Effects of serotonin precursors and melatonin on serum prolactin release in rats. Endocrinology, $93: 152$, (1973).

13) Kato, Y., Nakai, Y., Imura, H., Chihara, K. and Ohgo, S. : Effect of 5-hydroxytryptophan (5-HTP) on plasma prolactin levels in man. J. Clin. Endocr., $38: 695$, (1974). 14) Blask, D.E. and Reiter, R.J. : The pineal gland of the blind-anosmic female rat: its influence on medial basal hypothalamic LRH, PIF and/or PRF activity in vivo. Neuroendocrinology, $17: 362$, (1975).

15) Hirs, C.H.W., Stein, W.H., and Moore, S. : PeptiPes obtained by chymotryptic hydrolysis of performic acidoxidized ribonuclease. A partial structural formula for the oxidized protein. 'J. Biol. Chem., 221 : 151, (1956). 16) Bromer, W.W., Sinn, L.G. and Behrens, O. : The amino acid sequence of glucagon. II-IV. J. Am. Chem. Soc., 79 : 2898, (1957).

17) Harris, J.I. and Roos, P. Studies on pituitary polypiptide hormones. 1. The structure of beta-melanocyte-stimulating hormone from pig pituitary glands. Biochem. J., 71:434, (1959).

18) Margoliash, E. and Smith, E.L. : Isolation and amino acid composition of chymotryptic peptides from horse heart cytochrome c. J. Biol. Chem., $237: 2151$, (1962).

19) Margoliash, E. : Amino acid sequence of chymotryptic peptides from horse heart cytochrome c. J. Biol. Chem., 237:2161, (1962).

20) Kimmel, J.R., Kato, G.K., Paiva, C.M. and smith, E.L. : Tryptic digest of papain. 1. Isolation and sequence of some peptides from the oxidized protein. J. Biol. Chem., 237:2525, (1962). 21) Light, A. and Smith, E. L. : Chymotryptic digest of papain. IV. Peptides from the oxidized, carboxymethylated, and denatured protein. J. Biol. Chem., $237: 2537$, (1962).

Konigsberg, W. and Hill, R.J. : The structure of human hemoglobin. III. The sequence of amino acid in the tryptic peptides of the arpha chain. J. Biol. Chem., $237: 2547$, (1962).

Albert, A., Reganon, E., Saiz, J.L. and Usobiaga, P. : Physicochemical studies on tryptic digestion of bovine fibrinogen. Biochim. Biophys. Acta, 386 (2):382, (1975). $\quad 24)$ Yadley, R.A. and Chrambach, A. : Isohormones of human growth hormone. II. Plasmin-catalyzed transformation and increase in prolactin biological activity. Endocrinology, $93: 858$, (1973). 25) Abul-fadl, M.A.M. and King, E.J. : Purification of alkaline phosphatase by tryptic digestion. Biochem. J., $44: 434$, (1949).

26) Simpson, A.A., Simpson, M.H.W. and Kulkarni, P.N. : Prolactin production and lactogenesis in rats after ovariectomy in late pregnancy. J. Endocr., $57: 425$, (1973). 27) Vermouth, N.T. and Deis, R.P. : Rrolactin release and lactogenesis after ovariectomy in pregnant rats : effct of ovarian hormnnes. J. Endocr., $63: 13,1974$.

28) Bridges, R.S. and Goldman, B.D. : Ovarian control of prolactin secretion during late pregnancy in the rat. Endocrinology, $97: 496,1975$.

29) Neill, J.D. : Effect of "stress" on serum prolactin and luteinizing hormone levels during the estrus cycle of the rats. Endocrinology, 87 : 1192, 1970.

30) Neill, J.D. : Comparison of plasma prolactin levels in cannulated and decapitated rats. Endocrinology, $90: 568,1972$.

31) Valverde-R., C., Chieffo, V. and Reichilin, S. : Failure of reserpine to block ether-induced release of prolactin : physilogical evidence that stress induced prolactin release is not caused by acute inhibition of PIF secretion. Life Sciences, 12 (I) : 327, $1973 . \quad 32$ ) Terkel, J., Blake, C.A. and Sawyer, C.H. : Serum prolactin levels in lactating rats after suckling or exposure to ether. Endocrinology, $91: 49,1972$.

33) Schlein, P.A., Zarrow, M.X. and Denenberg, V.H. : The role of prolactin in the depressed or 'buffered' adrenocorticoid response of the rat. J. Endocr., 62:93, 1974.

34) Kann, G. and Martinet, J. : Prolactin levels and duration of postpartum anoestrus in lactating ewes. Nature, $257: 63,1975 . \quad 35)$ Maneckjee, R. and Moudgal, N.R. : The onset of oestrus and ovulation lactating rats. J. Reprod. Fert., $44: 313,1975$.

36) Schwert, G.W. and Takenaka, Y. : A spectrophotometric determination of trypsin and chymotrypsin. Biochim. Biophys. Acta, $16: 570$, 1955. 